bones.in triumph from Scyros to Athens, point to its having belonged to much the same period. The spear of Achilles in the temple of Minerva at Phaselis, and the sword of Memnon in the temple of Esculapius at Miomedia, were also of bronze, of which metal, as Patısanias observes, all the weapons of the heroic age were made. Had Augustus but known of the buried treasures of $\mathrm{My}$ cenæe when he was collecting the Arena Heroum for his museum at Caprea, the researches of Dr. Schliemann might have been in vain.

As it is, he is to be congratulated not only on the extent and importance of his discoveries, but also on his investigation having brought to light those horned Juno idols which he anticipated finding. His theory of some of the owl-like figures from Hissarlik bearing reference to the name of $v \lambda a v k \hat{\omega} \pi s^{\prime}{ }^{\prime} \mathrm{A} \theta \dot{\eta} \nu \eta$ has met with more ridicule than it deserved, and if the discovery of

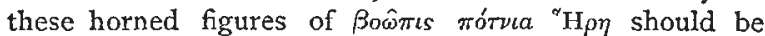
substantiated, Dr. Schliemann will be fairly entitled to claim the victory over his adversaries. Under any circumstances both he and his no less enterprising helpmeet deserve the most cordial thanks of all scholars and antiquaries.

J. E.

\section{PESCHEL'S "RACES OF MAN"}

The Races of Man and their Geographical Distribution. From the German of Oscar Peschel. (London: Henry

S. King and Co., 1876.)

THIS book appears from the preface to be founded on General A. von Roon's "Ethnology as an Introduction to Political Geography," though it is substantially a new work intended to form a complete manual of ethnology. The actual title is somewhat misleading, as no special prominence is given to problems of geographical distribution, while languages, myths, and mere tribal distinctions, are treated with great and somewhat bewil. dering detail. The perusal of a work like the present, which, with great labour attempts to bring together in a compact form, all the existing information as to the physical and mental characteristics of the various races of mankind, impresses one painfully with the still chaotic state of the infant science of anthropology. With an overwhelming mass of detail as to secondary and often unimportant characters, we find a frequent want of exact knowledge as to the chief physical and mental charac. teristics of the several races and sub-races.

Language, myths, habits, clothing, ornaments, weapons, are described in detail, while we are left without any sufficient information as to the stature, bodily proportions, features, and broad mental characteristics of many important groups of men. The reason is obvious. The former class of facts can be readily obtained by passing travellers; while the latter require the systematic observation of an intelligent resident and more or less skilled anthropologist, and can only be arrived at by means of careful measurements and long-continued observations. It is not sufficiently considered that in almost every part of the world there is more or less intermixture of races, brought about by various causes-as slavery, war, trade, and accidental migrations. Hence in many cases the passing traveller is altogether deceived as to the characters of the race, and any 'observations he may make are of little value. It-is only by a long residence among a people, by travelling through the whole district they inhabit, and by a more or less accurate knowledge of the surrounding tribes with whom they may be intermixed, that the observer is enabled to disentangle the complexities they present, and determine with some approach to accuracy the limits of variation of the pure or typical race. Unfortunately this has yet been done in comparatively few cases; but anthropologists are now becoming impressed with its importance, and we may soon hope to obtain a body of trustworthy materials, which may enable us to determine, with more confidence than is yet possible, the characters and the affinities of many of the best marked races of mankind.

We will now give a sketch of the mode in which the subject is dealt with in the present work, and point out some of the more striking merits and defects it possesses. The first and larger portion of the book treats of the various physical and mental characteristics of mankind, the latter portion being devoted to a systematic review of the races and tribal divisions. The introductory chapter treats of man's place in nature, origin, and antiquity; and while adopting the developmental theory as regards animals, argues with more or less force, against the Darwinian theory of the animal origin of man and especially against the influence of sexual selection. The hypothetical continent-Lemuria--is suggested as the most probable birthplace of the human race, and it is explained that this locality is "far more orthodox than it might at the first glance appear, for we here find ourselves in the neighbourhood of the four enigmatic rivers of the scriptural Edenthe Nile, the Euphrates, the Tigris, and the Indus." The unity of mankind as constituting a single species, is strongly urged, while the evidences of his antiquity are briefly but forcibly set forth. We are glad to see due weight giver to Horner's borings in the Nile valley, which we have always thought have been unduly depreciated. It is well remarked that the suggestion of the piece of pottery found at a depth of 39 feet baving fallen into an ancient well or tank, is altogether groundless, because this is only one out of a large number of fragments of bricks and pottery found at various depths over an extensive area, and there is certainly no reason why the one found at the greatest depth should have fallen into a well rather than any or all of the others. It seems not to have been considered, by those who have advanced this view, that a well at Memphis, close to the Nile, could not have been very deep, and that if it had been it would probably have been in use for many centuries, and would have become the receptacle, not of a solitary fragment of pottery, but of a whole collection of utensils, ornaments, and domestic implements, such as invariably fall into wells in the course of time. Moreover, a well 40 feet deep in the soft alluvium of the Nile must certainly have been lined with stone or brickwork, and have been protected at the top by some inclosure solid enough to have resisted the muddy inundation water, and it would almost certainly have been covered over to keep out sand and dust in the dry season. It would therefore be almost impossible to bore on the site of an ancient well without knowing it; so that no more hasty and unsound suggestion to avoid a supposed difficulty was ever made than this "well theory," and yet; strange to say, it has been almost uni- 
versally adopted as fatal to all calculations founded on these careful borings. It seems to be thought that although we must have facts to establish a theory, we need only have suppositions to overthrow them.

The next chapter-on the Physical Characters of the Races of Mankind-treats pretty fully of the brain and cranium, and also of the hair, but far less satisfactorily (owing to absence of material) of other physical characters; and the conclusion arrived at is "that neither the shape of the skull nor any other portion of the skeleton has afforded distinguishing marks of the human races; that the colour of the skin likewise displays only various gradations of darkness, and that the hair alone comes to the aid of our systematic attempts, and even this not always, and never with sufficient decisiveness."

The next chapter treats of Linguistic Characters. While speaking favourably of the imitative and interjectional theory of language, its powers are unnecessarily "limited to events connected with the production of sounds, for no such representation is possible of that which is perceived by sight or the sense of touch." It has, however, been often shown that roots derived from sounds or emotions may soon be applied by metaphor, analogy, or contrast, to a wide variety of meanings; and it may perhaps be something more than a coincidence, that the languages which possess the smallest number of primitive soundsthe Polynesian-belong to an area where from the total absence of mammalia and paucity of birds and insects the variety of natural sounds is extremely small. The chapter which treats of Social and Religious Development is very voluminous, occupying considerably more than one-third of the whole work, while more than seventy pages are occupied with an account of the various relifions, a large pari of which is modern history and has the smallest possible connection with ethnology. This chapter is fuill of facts intermingled with a good deal of more or less doubtful philosophy. We may call attention, however, to the view that cannibalism is not a character of the lowest state of savagery, but is "more frequently encountered exactly among those nations and groups of nations which are distinguished from their neighbours by their abilities and more mature social condition." The ancient Mexicans, the Fijians, the Battas of Sumatra, as well as the Fans, Niamniams, and Monbuttos of Central Africa are adduced as examples, and as likewise proving that it is not the absence of animal food that has led to the formation of the habit. On the question of the first discovery of fire there is much wasted argument, founded on the erroneous assumption that to obtain fire by friction $i$ a most laborious operation and always requires the combined labour of two persons (p. 143). On the contrary, either by the hand drill or by rubbing it is effected with great rapidity by one individual, and there is really no reason why it might not have been independently discovered in different parts of the world.

One of the best passages in this part of the work is that which treats of the influence of commerce on the migrations of nations (pp. 2IO-2I4). Humboldt has remarked that had not Columbus altered his course a few days before sighting America he would have landed in Florida, and the Spaniards would have peopled the United States instead of Central America, and the New World would now have had quite idifferent ethnographical fea- tures. This was a very crude and unphilosophical remark of Humboldt's, for, as our author shows, the portion of Amexica to be colonised by Spaniards was almost wholly determined by the presence of the precious metals. Wherever these were not found they marked on their charts a.s "worthless territories," and had they first discovered the present United States they would certainly have at once abandoned them. Agricultural colonies were not possible at that early period, and the first settlements of the French and English literally perished of starvation. Tobacco as a valuable article of commerce first made Virginia flourish. The demand for codfish in France caused Canada to become a French colony. The Russians have settled wherever furs were obtainable. Spices caused the Portuguese and Dutch to settle in the far East, while in modern times the attraction of gold has led to the peopling of California with Anglo-Americans. This interesting discussion is summed up with the remark :-

"We thus see how much we owe to the rare and precious products of the animal, vegetable, and mineral kingdoms, as the means by which human culture was spread, and as the baits which attracted national migrations, and we perceive that the regions which were fortunate enough to possess such treasures were the first to be drawn into the sphere of a higher culture; the direction in which civilisation has moved has frequently been prescribed by this influence."

In the last part of the work, devoted to a detailed exposition of the races of mankind, we have a somewhat peculiar primary division into seven groups. The first includes the inhabitants of Tasmania and Australia; the second, the Papuans of New Guinea and the adjacent islands; the third, the Mongoloid nations, including the Malayo-Polynesians and native Americans; the fourth, the Dravida of Western India; the fifth, the Hottentots and Bushmen ; the sixth, the Negroes ; and the last, the Mediterranean nations, answering to the Caucasians or Indo-Europeans of other ethrologists. The Tasmanians are said to have "exactly resembled the Australians in all points, except that the growth of the hair was more Papuan in character." The supposed resemblance of Australians to the aboriginal inhabitants of Central India is set aside as entirely without foundation, while they are said to be decidedly nearest of kin to the Papuans. These latter are associated with the Negritos and the Andaman Islanders. Notwithstanding that a wide-spread relationship between Papuan and Polynesian languages is affirmed (p. 342), yet the Polynesians are associated with the Malays as a Mongoloid sub-race, the Malayo-Polynesians, an association which the present writer holds to be radically erroneous. The American tribes are treated as a single homogeneous group which entered the continent from the north-west, and little weight is given to the great differences of mental and physical character which exist and which are certainly greater than can be explained by a comparatively modern origin from a single stock. Very much yet remains to be done in determining the successive waves of migration which have flowed into the American continent, and we bardly think our author is justified in ranking the American aborigines as far higher than the negroes, on the ground that the former have, quite independently, reached a much higher civilisation. Throughout, all this portion of the book a vast 
mass of information is given as to the tribal divisions, habits, languages, and migrations of the several groups; but these details often obscure those broader features of physical and mental peculiarity which are of most importance in arriving at correct conclusions as to the primary divisions of mankind and the true affinities of the various races.

It is impossible here to notice the many interesting questions which arise as we peruse the mass of facts and opinions set forth in such a work as this. Although unequal in treatment, and in many respects imperfect, it exhibits much labour and research, and treats in more or less detail every branch of the great and rapidly-developing science of anthropology; and it forms on the whole as good a manual of the subject as we are at present likely to obtain from a single author. It is to be hoped that when another English edition is required some wellinstructed anthropologist may revise and edit the work, so as to modify (by means of footnotes or otherwise) the unusual treatment of many questions of which our author gives a more or less one-sided exposition. ${ }^{2}$

ALFRED R. WALLACE

\section{OUR BOOK SHELF}

Ostriches and Ostrich Farming. By Messts. De Mosenthal and Harting. 8vo. pp. i.-xxii., r-246. (London: Trübner and Co., 1876.$)$

If ornithologists have regretted the apparent retirement of Mr. Harting for the last few years from the field of scientific research, they will find on consulting the present volume that his devotion during that time to popular science has not impaired his powers, but has perhaps tended to increase the gift which he always possessed in a high degree, of being able to present to his readers the details of science in interesting and attractive language. We have been induced to make the above remarks, inasmuch as no one would suspect that under the above title is comprised a very complete monograph of the Struthionizle from the pen of Mr. Harting, but such is really the case, for, out of a volume of. some 250 pages, threefourihs are occupied with the history of the ostrich and its kindred. This portion of the work is entirely written by Mr. Harting, and, like everything he undertakes, is executed with thorough conscientiousness. The true Ostriches (Struthio), the Rheas (Rhea), the Emu (Dromuceus), the Cassowaries (Casizarizus), and the Apteryges are all passed in review, and a complete monographic account given of each; the history of the ostrich and its distribution in times past and present being very exhaustively compiled. We can heartily commend the

I The translation is from the second edition, yet there are a considerable number of errors and oversights, some of which it may be useful to point out - Frst we must notice that the copious table of contents is rendered quite useless by the absence of a single reference to the pages at which the several chapters and sections begin or end. Ariong errors of act we notice (at p. 2) that the Hylobates is said to "stand far nearer to man than the other three highest apes ; "at p. 20, that the Dutch are not acchimatised in the East; at p. II7, that the Malays always use the word store in counting as "threc stones chickens" the fact being that stone or seed is used for inasinate objects only, tril for living things, as "three tails cbickens," \&c. ; at p. 204 "the Sunda, Banda, and Molncca 1slands," are said to have formerly bound together Asia and Australia, but by subsidence have become "gronps of islands in a shallow sea;" and again, at p. 205, the Gulf of Mexico and Caribbean seas are both sald to be shallow, and to show a Cormer contuection with the continent; p. 343, Papuans axe said to smelt iron ore; this I thin is quite enroned, thoigh on the coast they work iron brought them by the Malays and traders; at p- 344 the Papuans ate said to cultivate trees, and to possess "only seedless varieties of the bread fruit," the exact contrary beng the fact; at p. $4^{\mathrm{r}} 3$ guinea-fowls are put as natives of the New World, and "prairie dogs" as domestic animals; at p. 4I, the "ounce" is put for the " Jaguar;" at p. 473 " (Crax) guinea-fowls," are said to be bred for food. Of oversights or mistranslations we notice at p. 85, lines xo-II, figures which are quite unintelligible; $p .366$, line $x$, "allows too long" is a bad translation; p. 368 , line 2 , "outbreak of the pestilence" xefers to the nutmeg disease, $-\mathbf{A}$. R. W. illustrations in this volume, very good full-page drawings of the principal Struthious forms, having been designed by Mr. T. W. Wood, while the Zoological Society has allowed the woodcuts which have illustrated Dr. Sclater's various memoirs on the Struthionida to be utilised, so that a very complete monograph of these birds is the result.

Mr. De Mosenthal's portion of the work is confined to the practical "Ostrich Farming," and seems to be extremely well worked out, giving a history of the development of the pursuit from its first commencement. The author's personal experience has been confined to Solth Africa, where ostrich-farming has acquired its chief importance, but the statistics of the exportation of feathers from the other parts of Africa show that at present the greatest trade is done through Egypt, the annual value of the exports from this country being $250,000 \%$. The Cape comes next with exports to the value of $20,000 \%$ less, while from Barbary the value is 100,000 l. annually, from Mogador 20,000l., and Senegal 3,000l. The whole of the process of the artificial incuoation of the eggs is described with minuteness, and altogether the contribution is most entertaining and instructive. The volume concludes with an appendix giving consular and other reports, all of which supply important statistics and interesting historical matter bearing on the subject.

Die Darwin'sche Theorien und ihre Stellung zur Philosophie, Religion und Moral. Von Rudolf Schmid, Stadtpfarrer in Friedrichshafen. (Stuttgart, I876.)

A GLANCE through this book will not satisfy the reader that the great problems of modern thought are to be settled even by the well-meant essays of a well-read pastor. It is one of the "reconciliations" of science and religion, so common in England, but less so in Germany, where people are in general unwilling to check views on scientific questions by their relation to theology. The author impresses on his readers that the theory of universal law is compatible with the Christian doctrine of miracles, and that the Darwinian hypothesis of development may really receive strong suppori from the doctrine of human development in a future state. But his arguments prove little or nothing one way or the other. Next, turning to the Creation, we find him placidly remarking that the order of its stages is given differentiy in Genesis and again in Job, his inference being that neither order is "binding on us." The six days, in his opinion, are not natural days, nor are they geological periods, for neither would this fit with the geological evidence; he therefore concludes that they are "divine days," whatever that may mean. Such reading ought to suggest to religious minds the serious question whether disbelief can do so much harm as the habit of perverting and mystifying belief. We may hope that when theologians have become more familiar with the theory of evolution as manifested in the development of religious ideas themselves, their reconciliation of man's religious tendencies with his scientific knowledge may be placed on a higher basis than in such attempts as this, of which the weakness is only made more conspicuous by its good intention.

E. B. T.

\section{LETTERS TO THE EDITOR}

[The Editor does not hold himelf responsible for opinions expressed by his correspondents. Neither can he undertake to return, or to correspond with the zeriters of, rejected manuzscripts. No notice is taken of anonymous communications.]

\section{Sea Fisheries}

As an enthusiastic amateur sea-fisher some twenty years ago on the Canadian coast of what the Americans call the "herringpond," perhaps you will allow me to make a remark or two on Mr. Holdsworth's letter in NATURE, vol. xv., p. 135. Long absence from that happy hunting-ground has not beclouded my 